\title{
Retraction of STEM Education in English of Early Childhood in China
}

Wenxiao Zhao *

Issue Date: 18 November 2018

Original Article: STEM Education in English of Early Childhood in China EURASIA J. Math., Sci Tech. Ed (2018), 14(6), 2367-2378.

https://doi.org/10.29333/ejmste/89596

This document states that the Article is retracted by request from the author.

\section{http://www.ejmste.com}

(C) 2019 by the authors; licensee Modestum Ltd., UK. This article is an open access article distributed under the terms and conditions of the Creative Commons Attribution License (http://creativecommons.org/licenses/by/4.0/). 囚 Sfl_zhaowx@ujn.edu.cn (*Correspondence) 